\title{
Bribing Behaviour and Sample Selection: \\ Evidence from Post-Socialist countries and Western Europe
}

\author{
Artjoms Ivlevs ${ }^{1}$ and Timothy Hinks ${ }^{2}$
}

University of the West of England

\{This is an update of the previous version of UWE working paper 1208; this version is dated $14 / 01 / 13$ \}

\begin{abstract}
We study the individual-level determinants of bribing public officials. Particular attention is paid to the issue of respondents' non-random selection into contact with public officials, which may result in biased estimates. Data come from the 2010 Life in Transition Survey, covering 30 post-socialist and five Western European countries. The Heckman probit model results suggest that the elderly are less likely to bribe public officials, while linguistic minorities, people with higher perceived relative income and those with lower trust in public institutions are more likely to bribe. The results also show that not accounting for sample selection effects produces an upward bias in estimated coefficients.
\end{abstract}

JEL classification: $C 13, D 73, P 2$.

Keywords: Bribing, Sample Selection, Transition economies

\footnotetext{
${ }^{1}$ (Corresponding author) Department of Accounting, Economics and Finance, University of the West of England, Bristol BS16 1QY, UK. Tel: +44 11732 83943, Fax:+44 11732 82289, E-mail: a.ivlevs@uwe.ac.uk

${ }^{2}$ Department of Accounting, Economics and Finance, University of the West of England, Bristol BS16 1QY, UK. Tel: +44 11732 82741, Fax:+44 11732 82289, E-mail: timothy.hinks@ uwe.ac.uk
} 


\section{Introduction}

There is a general agreement among academics and policymakers that corruption leads to inferior socio-economic outcomes. A large and well-established body of literature suggests that, at country level, higher corruption is associated with lower economic growth (Mauro, 1995; Everhart et al., 2009; Johnson et al., 2011), higher inequality and poverty (Gupta et al., 2002; Jong-sun and Khagram, 2005), and lower international trade and foreign investment (Wei, 2000; Cuervo-Cazurra, 2006; Egger and Winner, 2006; Jong and Bogmans, 2011). In this context, fighting corruption has become a major preoccupation for governments in many developing, transition and, in certain cases, developed countries across the world.

To deal with corruption, one must know its causes. These causes are likely to be both 'external' and 'internal' to individuals involved in corrupt exchanges, and many of these causes can be successfully targeted by policymakers. Externally - at country level - higher levels of corruption are correlated with a slower pace of structural reforms (Iwasaki and Suzuki, 2012), less freedom of the press (Brunetti and Weder, 2003), a lower ratio of government to manufacturing wages (Van Rijckeghem and Weder, 2001), a lower share of women in the labour force (Swamy et al., 2001), a lower share of the Protestant population (Treisman, 2000) and higher levels of official development aid (Ali and Isse, 2003).

'Internal' causes of corruption are also of interest, as they help the policymakers understand why, within a particular country, some people are more likely to engage in corrupt acts than others. An increasing availability of large-scale survey data, as well as a wider recognition of the fact that corrupt acts are 'performed' by individuals, has recently led to a number of empirical papers on the individual-level determinants of corruption behaviour and corruption attitudes (Gatti et al., 2003; Mocan, 2008; Guerrero and Rodriguez-Oreggia, 2008; Hunt, 2007; Hunt and Laszlo, 2012; Tavits, 2011; Truex, 2011). This literature suggests, for example, that wealthier/richer people are more prone to corruption: wealthier people have been shown to be more likely to pay bribes (Guerrero and Rodriguez-Oreggia, 2008; Hunt and Laszlo, 2012), be asked for bribes by public officials (Mocan, 2008) and find corrupt behaviour justifiable (Gatti et al., 2003). 
This paper continues the exploration of the individual-level determinants of corruption and makes several contributions to the literature. First, it addresses a methodological gap in the empirical literature - an issue of potential sample selection bias which arises from a non-random selection, based on respondents' unobservable characteristics, into contact with public officials. To deal with such sample selection bias, we apply a Heckman correction procedure and show that not accounting for selection effects produces an upward bias in the estimates of the determinants of bribery. To date, the empirical literature has largely overlooked possible sample selection effects when estimating the determinants of bribing. For example, Tavits (2011) has survey information of whether respondents have ever paid a bribe but not on whether they have ever had a contact with public officials. She, therefore, estimates the probability of bribing on a broad sample of users and non-users of public services - an approach which is likely to suffer from the sample selection bias based on both the observable and unobservable characteristics. Guerrero and Rodriguez-Oreggia (2008) analyse only the sub-sample of public official users, but do not address the selection into contact with officials. Hunt (2007) and Hunt and Laszlo (2012) look at the determinants of both the selection into contact with public officials (which they call a first stage of the corruption process, having indirect effect on bribery) and the probability of paying a bribe once the contact has taken place (second stage, direct effect on bribery). They do not, however, explicitly take into account the potential effect of unobservable characteristics in the first stage which might lead to a sample selection bias in the second stage. In this context, the Heckman correction approach, that we use on our study, is particularly advantageous: it allows us, in a unified framework, to deal with the sample selection bias and also reveals the determinants of selection into contact with public officials.

The second contribution of the paper consists in using a large, recent (2010) and yet unexplored 'Life in Transition-2' survey, administered in 2010 in 30 economies of Central and Eastern Europe and Central Asia and five Western European countries. An important advantage of the data is that the respondents were asked about their actual corruption behaviour - paying a bribe to a public official. Much of the previous literature on the micro-determinants of corruption has concentrated on attitudes towards corruption (Soot and Rootalu, 2012; Gatti et al., 2003; Truex, 2011) and the 
probability of being asked for a bribe (Mocan, 2008). Several studies (Tavits, 2010; Hunt and Laszlo, 2012; Hunt, 2007; Guerrero and Rodriguez-Oreggia, 2008) have addressed the actual bribing behaviour, but only in the context of one or two countries (Estonia, Peru, Uganda, Mexico). To the best of our knowledge, this is the first study to focus on the ultimate measure of corruption behaviour - paying a bribe - in a multi-country setting.

The principal geographical focus of this paper is on the post-socialist economies of Central Eastern Europe and Central Asia. Despite the attempts of these countries to build well-functioning and transparent governance systems, corruption remains a widespread phenomenon ${ }^{3}$ (Transparency International, 2011; Iwasaki and Suzuki, 2012) and a major problem for policymakers. While there is general agreement that corruption is high in the post-socialist world, little is known about the drivers of bribing behaviour at the individual level. This paper seeks to reveal the microdeterminants of bribery for the whole region, as well as for different geo-political country groups within Central Eastern Europe and Central Asia. We also compare the individual-level drivers of bribing in the post-socialist world with those in five Western European countries.

The remainder of the paper is structured as follows. Section two explains why a sample selection bias might arise in the analysis of micro-determinants of bribery. Section three presents the data, variables and empirical strategy. Section four reports and discusses the results, followed by conclusions in section five.

\section{Sample selection bias and bribery.}

Consider an estimation of the effects of socio-demographic characteristics, such as income, education and age, on the likelihood of bribing public officials. Assume that a sample, randomly drawn from the broad population of interest, is available for this

\footnotetext{
${ }^{3}$ The high levels of corruption in the region can be attributed to several factors: high corruption could be a legacy of the Communist regime where it was considered "institutionalized, socially necessary evil for achieving goals and maintaining the national economy" (Iwasaki and Suzuki, 2012, p. 54); it could have resulted from the plan-to-market transition process itself, which, in the absence of strong rule of law, created ample opportunities for corrupt exchange (Tavits, 2011; Iwasaki and Suzuki 2012); and, finally, it could be linked to mentality, culture and considered a norm in a particular society.
} 
purpose. The incidence of bribery (whether the respondent paid a bribe or not) is observed for only those respondents who have had contact with public officials; the information on bribing is missing for all other respondents. A typical regression, estimating the effects of socio-economic characteristics on the likelihood of bribery, would be run on a sub-sample of public official users and exclude the non-users.

If the sub-sample of public official users is drawn randomly from the underlying population, users' characteristics, both observable and unobservable, should be similar to those of the underlying population. However, if people with certain characteristics self-select into contact with public officials, the sample draw is no longer random. This could mean that factors affecting the selection into contact with public officials also influence the decision to pay a bribe to public officials. If these characteristics are observable, the sample selection bias that arises can be corrected by including them as regressors in the outcome (bribing) equation (Vella, 1998).

However, the bias remains, if there are unobservable characteristics that influence the selection process. The unobservables will then be automatically correlated with the observables in the outcome equation (even if they are not correlated in the underlying population). As the unobservable characteristics are included in the error term, the observable variables of interest will be correlated with the error term in the outcome (bribing) equation, resulting in biased estimates.

Formally, the bribing model with sample selection can be described as follows. Following the logic a standard probit model, assume that an individual $i$ 's propensity to bribe is captured by an underlying latent variable, $y_{i}{ }^{*}$, which is determined by a set of the respondent's characteristics, $X_{i}$, and an independent and normally distributed error term, $u_{1 i \text { : }}$

$$
y_{i}^{*}{ }^{* b r i b e}=X_{i} \beta+u_{1 i}, \quad u_{i} \sim N(0,1)
$$

The actual bribing behaviour is captured by a binary variable $y_{i}^{\text {bribe }}$ which is related to the latent propensity to bribe $y_{i}{ }^{*}$ :

$$
y_{i}^{\text {bribe }}=1\left(X_{i} \beta+u_{1 i}>0\right)
$$


The bribing behaviour, however, is observed only if contact with public official has taken place. The binary variable capturing contact with public officials, $y_{i}^{\text {contact }}$, depends on the latent propensity to contact public officials, $y_{i}{ }^{{ }^{*} \text { contact }}$ :

$$
\begin{array}{ll}
y_{i}{ }^{\text {contact }}=1\left(y_{i}{ }^{* \text { contact }}>0\right) & \\
y_{i}{ }^{* \text { contact }}=Z_{i} \gamma+u_{2 i}, & u_{i} \sim N(0,1),
\end{array}
$$

where $Z_{i}$ is a vector of respondent characteristics determining selection into contact with public officials and $u_{2}$ is an independent and normally distributed error term.

It can be shown (see, e.g., Wooldridge, 2002) that the sample selection bias arises if the error terms in the outcome (bribing) and selection (contact) equations are correlated: $\operatorname{corr}\left(u_{1}, u_{2}\right)=\rho, \rho \neq 0$.

A procedure to correct the sample selection bias for a continuous dependent variable models was proposed by Heckman (1979) and can be easily extended for binary response models (see e.g. Van der Ven and Van Praag, 1981; Baum, 2006).

Essentially, the correction procedure consists of estimating a vector of error terms in a probit selection equation (obtaining inverse Mills ratios) and including them as an additional regressor in the outcome equation. As a result, the part of the error term correlated with the regressor of interest in the outcome equation is removed and unbiased estimates of the variables of interest are obtained. The heckprob command in Stata provides consistent, asymptotically efficient estimates of all the parameters of the model and reports an estimate of $\rho$ - the coefficient of correlation of the error terms in the selection and outcome equations. A statistically significant correlation indicates that the sample selection bias is present and the Heckman correction procedure should be applied.

Theoretically, the identification of the two-stage Heckman correction model is possible when the same set of explanatory variables are included in the selection and outcome regressions. In practice such identification, based solely on different distributional assumptions of the error terms, is likely to be weak (Wooldridge, 2002; Baum, 2006). It is strongly recommended to include an additional identifying variable in the selection equation - in our case, a variable that would affect the probability of 
contacting public officials, but not directly the probability of bribing conditional on public official use. In other words, $X$ must be a subset of $Z$ in equations (1)-(4).

\section{Data and variables.}

\subsection{Data.}

To test for possible sample selection bias and find the determinants of bribery, we use data from the "Life in Transition 2" survey (LITS-2), conducted by the EBRD and the World Bank in autumn 2010. Thirty post-socialist economies of Central and Eastern Europe and Central Asia, as well as five Western European countries (France, Germany, Italy, Sweden and the UK), participated in the survey. The nationally representative samples consist of 1,000 respondents per country (1,500 respondents in the case of Russia, Ukraine, Uzbekistan, Serbia, Poland and the UK). In each country, the households were selected according to a two-stage clustered stratified sampling procedure. In the first stage, the frame of primary sampling units was established using information on local electoral territorial units. In the second stage, a random walk fieldwork procedure was used to select households within primary sampling units. Steves (2011) provides the survey summary, including detailed information on survey design and implementation methodology.

Our main analytical focus will be on the broad region (30 countries) of Eastern Europe and Central Asia (CEECA). We exclude the five Western European countries - the UK, Germany, France, Italy and Sweden - from the main sample, as they are likely to represent a qualitatively different group compared with the post-socialist region. Western countries have longer histories of functioning democracy and more transparent institutions, which would make corruption there a less widespread phenomenon. In addition, Hunt (2007) suggests that the stigma associated with answering questions about bribery honestly may be lower in high-corruption countries (such as post-socialist economies) than low-corruption countries (such as industrialised Western democracies). This is because people in high-corruption countries view bribery as inevitable and the fault of the system, and will talk more easily about it. 
As a sensitivity check, we will test our model on several sub-samples of the broad CEECA region, created along geo-political lines: the Balkans, the Baltics, the Caucasus, Central Asia, Central Europe and Slav ex-USSR. We will also run our model on the subsample of five Western European countries and compare the results to those obtained on the post-socialist countries.

\subsection{Variables}

\section{$\underline{\text { Dependent variable }}$}

Whether a bribe is made or not is subject to contact with public officials/institutions. The LITS-2 survey contains several questions relating to public official use and selfreported corruption behaviour. This paper uses two questions from it. With reference to eight types of public services (interacting with road police; requesting official documents (visa, passport) from authorities; going to courts for a civil matter; receiving public education (primary or secondary); receiving public education (vocational); receiving medical treatment in the public health system; requesting unemployment benefits; requesting social security benefits), the first question asks, "During the past 12 months have you or any member of your household used these (eight) services?" (italics added). If answered in the affirmative, then information is gathered on whether "... any member of your household (has made) an unofficial payment or gift when using these services over the past 12 months?" (italics added). The first question will capture the selection into contact with public officials/ institutions; the second question will capture bribery conditional on contacting public officials.

Table 1 reports, for each type of public official/institution, 1) the number of bribery episodes, 2) the proportion of bribery episodes relative to the full sample, 3) the proportion of respondents who have used a public official relative to the full sample, and 4) the proportion of bribery episodes relative to the number of respondents who have contacted a public official. In absolute terms, the highest number of bribery episodes is observed in the public health system (17.5\% of all respondents were 
involved in bribery), followed by the road police (5.7\%) and requesting official documents (4.2\%). Together, these three types of public officials account for $75 \%$ of all bribery episodes. However, if the comparison is made relative to those respondents who have used a public official, the road police emerges as the most corrupt public service (30.3\% of those who have interacted with road police paid a bribe), followed by the public health system (25.5\%) and the vocational public education (18.5\%). Courts, unemployment and other social security services have the lowest rates both in terms of official use (4-10\%) and giving a bribe conditional on official use (10-13\%).

Table 1. Distribution of bribery and official use across official types

\begin{tabular}{lcccc}
\hline & $\begin{array}{c}\text { Bribery } \\
\text { episodes } \\
\text { (bribe was } \\
\text { paid) }\end{array}$ & $\begin{array}{c}\text { Bribery rate } \\
\text { (relative to } \\
\text { total sample) }\end{array}$ & $\begin{array}{c}\text { Public official } \\
\text { use rate } \\
\text { (relative to total } \\
\text { sample) }\end{array}$ & $\begin{array}{c}\text { Bribery rate } \\
\text { (relative to } \\
\text { public } \\
\text { official use) }\end{array}$ \\
\hline Road police & 1901 & 0.057 & 0.188 & 0.303 \\
Requesting documents from authorities & 1386 & 0.042 & 0.230 & 0.181 \\
Courts & 197 & 0.006 & 0.044 & 0.134 \\
Public education (primary and secondary) & 1302 & 0.039 & 0.254 & 0.154 \\
Public education (vocational) & 1014 & 0.030 & 0.164 & 0.185 \\
Public health system & 5839 & 0.175 & 0.687 & 0.255 \\
Unemployment benefits & 176 & 0.005 & 0.054 & 0.098 \\
Other social security benefits & 320 & 0.010 & 0.095 & 0.101 \\
\hline
\end{tabular}

Source: Life on transition-2 survey (2010).

\section{$\underline{\text { Explanatory variables }}$}

Following the empirical literature on the micro-determinants of corruption behaviour and attitudes (Tavits, 2010; Guerrero and Rodriguez-Oreggia, 2008; Soot and Rootalu, 2012; Hunt and Lazslo, 2012; Hunt, 2007; Truex, 2011), our regressions will include the following respondent characteristics: dummy variables for gender, six age groups, ${ }^{4}$ three education levels (primary, secondary, tertiary) and being employed; and the following household-level variables: linguistic minority status (if the main language spoken in the family is different from the official language(s) of the country), a self-reported position on an imagined ten-step income ladder, where the

\footnotetext{
${ }^{4}$ The survey also contains information on the household heads' gender and age. We have checked the robustness of our results to using these variables instead of the respective respondent characteristics the results remain qualitatively unchanged. This is partly because in the $61 \%$ of cases the respondents were the heads of households (Steves, 2011).
} 
first (tenth) step captures the poorest (richest) 10\% of the country (a variable ranging from 1 to 10), ${ }^{5}$ and dummy variables for three types of settlement (rural, urban, and metropolitan).

In addition, we want to include variables capturing respondents' trust in institutions and trust in people. The literature suggests that those with a high level of trust in public institutions are less likely to tolerate corruption and break the law (Soot and Rootalu, 2012; Marien and Hoodge, 2011). Therefore, we expect they will also be less likely to be involved in bribery. Institutional trust will be captured by a composite variable, ranging from 4 (complete distrust) to 20 (complete trust), formed by adding trust in four institutions: 1) the government/ cabinet of ministers, 2) local government, 3 ) courts and 4) the police (trust in each institution ranges from "complete distrust" (1) to "complete trust" (5)).

We also include a variable capturing trust in people, as one could argue that participants involved in an illegal transaction need to trust each other. The variable is based on the question: "Generally speaking, do you think most people can be trusted with answers range from "complete distrust" (1) to "complete trust" (5). Tavits (2011) considered trust in people as a potential determinant of the probability of paying a bribe in Estonia, but obtained a statistically insignificant coefficient. We want to test the significance of this variable in a broader sample on European and exUSSR countries.

Finally, to control for all country-wide influences (historical, cultural etc.) on household corruption behaviour, all regressions will include country-fixed effects.

\subsection{Estimation strategy}

To deal with a potential sample selection bias, when the determinants of bribery are estimated on a potentially non-random sample of public official users, we apply the Heckman correction procedure. To operationalise the model, we need an

\footnotetext{
${ }^{5}$ Unfortunately, the survey does not contain information on the actual household (or individual) income. We have considered using information on household expenditures on different goods (food, utilities, transport, education, health, clothing and durable goods) as a proxy for household income, but have decided against it, as the "do not know"/ non-response rate for several of these expenditure categories is as high as $18 \%$ (and much higher for particular countries - e.g., $66 \%$ missing answers for the expenditure on durable goods in Uzbekistan).
} 
identification variable which would affect the probability of interaction with public officials but not necessarily the probability of making a bribe. To generate such an identification variable, we consider particular household/ respondent circumstances that are likely to increase contact with each type of public officials/institutions. Thus, we observe that households having a car are more likely to interact with road police; households with children are more likely to contact primary and secondary education establishments, as well as institutions in charge of social security benefits; students are more likely to contact vocational education establishments, as well as request official documents (e.g. passports); the less healthy are more likely to receive medical treatment; those who have recently lost job are more likely to contact institutions in charge of unemployment benefits; and those who rent or have inherited their house/flat are more likely to go to courts for a civil matter. We use this information to construct a binary variable (for each type of public official), which takes the value of 1 if the characteristic is observed and 0 otherwise.

Given that each respondent was asked about the actual corrupt behaviour eight times in consideration of eight different types of public officials - we follow Hunt and Laszlo (2012) to generate a stacked dataset which contains eight observations per household corresponding to interactions with eight institution/public official types. The unit of observation thus becomes the household-public official pair. To control for possible interdependence of responses provided by the same household and account for different types of institutions/officials, we cluster standard errors at the household level and include dummy variables for each type of public official in both the selection and outcome equations.

The socio-demographic characteristics (age, gender, education, income, minority status, employment status and the area of residence), institutional trust, interpersonal trust, as well as country fixed effects, are included in both the selection into contact and outcome equations.

Besides comparing the results of the outcome equation in the Heckman correction model with a naïve probit regression, which does not account for sample selection, we will report the determinants of selection into contact with public officials. They are of interest, as selection into contact could be viewed as an integral part of the bribing 
process: e.g., Hunt (2007) and Hunt and Laszlo (2012) posit that factors increasing the need for public services increase bribery indirectly.

\section{Results}

\section{Base results}

Table 2 reports the results of the two stages - bribery once contact with public officials has taken place and selection into contact with public officials - of the Heckman probit model, as well as those of a naïve probit model, estimated on a sample of public official users and not correcting for sample selectivity. Both models are estimated for the broad region of Central Eastern Europe and Central Asia. To facilitate the interpretation of the results, only marginal effects are reported. ${ }^{6}$

Column (1) of Table 2 reports the marginal effects of the Heckman correction model's outcome equation, revealing several statistically significant individual-level determinants of bribery and highlighting a considerable heterogeneity of the probability of bribing public officials at country level. Considering sociodemographic characteristics, respondents aged 55-64 and 65+ are 2.6 and 1.7 percentage points, respectively, less likely to bribe public officials, compared with individuals aged 34-45 (the reference group). This finding is consistent with Guerrero and Rodriguez-Oreggia (2008), Mocan (2008) and Soot and Rootalu (2012), who find that the elderly are less likely to pay bribes, be asked for bribes by public officials and tolerate corruption.

The linguistic minorities are 1.4 percentage points more likely to pay bribes. This finding is corroborated by the results of two studies on corruption in Estonia: Soot and Rootalu (2012) find that the ethnic minorities are more likely to tolerate corruption and have lower corruption awareness, and Tavits (2010) finds that minority public officials are more likely to engage in hypothetical corrupt deals. Several explanations of why the minorities are more likely to engage in corruption can be provided. First, the minorities are concentrated in certain sectors of the economy (e.g., the informal

\footnotetext{
${ }^{6}$ The full econometric output is available on request.
} 
sector) which are more conducive to corrupt behaviour. Second, minorities, who are often more vulnerable and less able to seek/obtain protection, could be an easy target for extortion by public officials. Third, historical factors might play a role: in many countries of our sample, today's linguistic minorities originate from the former political elites (e.g. the Russian-speakers in the successor states of the USSR). These political elites might have been particularly prone to corruption under the previous regime (Iwasaki and Suzuki, 2012), and transferred their corruption attitudes and behaviour to the present day.

Richer individuals appear more likely be involved to bribery: moving ten steps (from the lowest to the highest) on the imaginary income ladder is associated with a 5 percentage points higher likelihood of bribery. Overall, the finding conforms with existing literature on micro-determinants of corruption: wealthier people have been found to be more likely to pay bribes conditional on contact with public officials (Hunt and Lazslo, 2011; Guerrero and Rodriguez-Oreggia, 2008), be asked for bribes by public officials (Mocan 2008) and find corrupt behaviour justifiable (Gatti et al., 2003). Typical explanations for richer individuals' higher propensity to bribe include their greater ability to pay, their higher opportunity costs of time, as well a conjecture that the rich are a prime target for corruption-prone public officials. ${ }^{7}$

Institutional trust is a strong determinant of the probability of paying a bribe. A one unit increase on the institutional trust scale ( 4 - complete distrust, 20 - complete trust) is associated with a 0.8 percentage point lower likelihood of paying a bribe. The finding is consistent with Soot and Rootalu (2012), who find that people with more trust in institutions tolerate corruption less and have a stronger awareness of corruption. The causality, however, could run in both directions. In particular, people who have experienced corruption-free encounters with public officials may develop a deeper trust in public institutions. If this is the case, the obtained coefficient on institutional trust is upward biased and should be interpreted with caution.

\footnotetext{
${ }^{7}$ Note, however, that a reverse causality between income and bribery may exist if people engage in bribery in order to increase their income; we would then observe an upward bias in the income variable estimates.
} 
The road police (the reference group) appear to be the most corrupt public service in our sample. It is followed by the public health services (people are 2.4 percentage points less likely to pay bribes to the public health officials relative to the road police), institutions issuing official documents, courts and vocational education establishments (7.7-8.5 percentage points less likely), and primary and secondary schools, and institutions dealing with unemployment benefits (10.5-11.7 percentage points less likely). Among the eight public institutions/ services, those dealing with social security benefits other than unemployment appear to be the least corrupt (12.4 percentage points lower likelihood to pay bribes compared to the road police).

Controlling for individual characteristics, we observe an important heterogeneity of self-reported bribery rates at the country level. Compared to Poland (the reference country), people in Kosovo, Georgia, Slovenia and Croatia are 5-8 percentage points less likely to pay bribes to public officials. In several countries - FYR of Macedonia, the Czech Republic and Slovakia - the likelihood of being involved in bribery is the same as in Poland. However, people are 4-7 percentage points more likely, relative to Poland, to pay bribes in Bosnia and Herzegovina, Bulgaria, Serbia, Latvia, Turkey and Estonia; 10-18 percentage points more likely to pay bribes in Armenia, Montenegro, Hungary Mongolia, Belarus and Russia; 22-24 percentage points more likely to pay bribes in Kazakhstan, Romania, Moldova and Lithuania; and, finally, 4163 percentage points more likely to pay bribes in Ukraine, Uzbekistan, Albania, Tajikistan, Kyrgyzstan and Azerbaijan. Note that the country dummies capture the aggregate effect of all possible country-level influences on conditional bribery rates; by construction, they do not allow us to isolate the effects of separate country-level factors. However, one notices some association between the GDP per capita and conditional bribery rates (bribery tends to be more widespread in poorer countries). Also, the ex-USSR Central Asian states tend to have higher conditional bribery rates than other countries in the sample.

To find out whether the sample selection bias is present in the model, we look at the estimated rho term, which captures the correlation of error terms in the selection and outcome equations. It is highly significant $(\mathrm{p}=0.009)$, meaning that the sample selection bias is present, the naïve probit results would be inconsistent, and the Heckman selection procedure should be applied. Comparing the findings of the 
Heckman correction model with the results of a naïve probit, which does not account for sample selection (Column 3), we observe larger (in absolute terms) marginal effects in the latter. Not controlling for selection effects thus produces an upward bias in coefficients (and marginal effects). For instance, the naïve probit suggests that people are 4 percentage points less likely to bribe public health officials than the road police; this declines to 2.4 percentage points when the sample selection bias is corrected for. On average, the marginal effects in the naïve probit are 19 percent higher than in the Heckman probit. $^{8}$

Before we turn to the determinants of bribing behaviour and the presence of sample selection bias in different country groups, it is useful to consider the factors which affect the probability of being selected into contact with public officials (the selection equation of the Heckman correction model; Column 2). Selection into contact can be viewed as having an indirect effect on bribery (Hunt, 2007; Hunt and Laszlo, 2012).

The results suggest that, compared to people aged 35-44 (the reference group), those aged 18-24 and 25-34 are 1 and 2 percentage points, respectively, less likely to contact public officials. Beyond the age group 35-44, the demand for public services declines with age: compared with the reference group 35-44, those aged 45-54, 55-64 and $65+$ are 1.2, 4.5 and 7.2 percentage points, respectively, less likely to contact public officials. Thus, people aged 34-45 are the most active users of public services, while the elderly are the least active. This finding could be explained by lower engagement in the labour market and lower family commitments of the elderly.

Linguistic minorities are 0.6 percentage points less likely to contact public officials, which could reflect the importance of mastering the official language of the country to consume public services. The more educated tend to contact public officials more: compared with people with secondary education, those with primary education are 1.3 percentage points less likely, and those with tertiary education are 0.9 percentage points more likely, to contact public officials. One could explain this finding by a more active involvement of the highly educated in activities, such as travelling and

\footnotetext{
${ }^{8}$ The number of 19 percent was obtained by comparing the marginal effects in the Heckman probit and the naïve probit. First, for each regressor, the relative change in the absolute value of the marginal effect was calculated; second, an average of these relative changes was taken.
} 
personal health care, which necessitate contacting public officials. The more educated may also find it easier to go through the bureaucracy associated with the consumption of public services. Note that perceived position on an imaginary relative income ladder is not statistically significant in predicting selection into contact with public officials.

Being employed is a statistically significant determinant of selection into contact, although its economic impact is small (the employed are 0.6 percentage points more likely to contact public officials). Metropolitan dwellers are 0.9 percentage points more likely to use public services relative to people in smaller urban areas, which could be explained by a high concentration and variety of public service providers in metropolitan areas. Finally, greater trust in people is associated with a higher consumption of public services. The effect, however, is only marginally significant and economically small: an extra step on the 1 (no trust) -5 (complete trust) interpersonal trust scale increases the probability of being selected into contact by 0.2 percentage points.

Considering the country fixed effects, the least intensive contact with public officials is observed in Poland, Armenia and Hungary (no statistically significant difference compared with the reference category Poland), and the most intensive in Albania, Azerbaijan, Kosovo and the FYR of Macedonia (16-31percentage points more likely to contact officials compared with Poland). This heterogeneity could be explained by the way in which public services are provided in different countries (e.g., they could be provided electronically, without having a physical contact with public officials), as well as the availability of privately provided alternatives to public services (e.g., private education and healthcare can be more present/accessible in some countries). 
Table 2. Determinants of bribery and contact with public officials, Heckman probit and naïve probit marginal effects

\begin{tabular}{|c|c|c|c|}
\hline & \multicolumn{2}{|c|}{ Heckman probit } & \multirow[b]{2}{*}{$\begin{array}{l}\text { Naïve } \\
\text { probit }\end{array}$} \\
\hline & $\begin{array}{l}\text { Paid a bribe } \\
\text { (Outcome) }\end{array}$ & $\begin{array}{c}\text { Contacted } \\
\text { official } \\
\text { (Selection) }\end{array}$ & \\
\hline & {$[1]$} & {$[2]$} & {$[3]$} \\
\hline Female & -0.005 & -0.002 & -0.006 \\
\hline \multicolumn{4}{|l|}{ Age group } \\
\hline $18-24$ & -0.009 & $-0.010 * * *$ & -0.011 \\
\hline $25-34$ & 0.003 & $-0.020 * * *$ & 0.004 \\
\hline $35-44$ & Ref. & Ref. & Ref. \\
\hline $45-54$ & -0.008 & $-0.012 * * *$ & -0.010 \\
\hline $55-64$ & $-0.026 * * *$ & $-0.045^{* * *}$ & $-0.031 * * *$ \\
\hline $65+$ & $-0.017 * * *$ & $-0.072 * * *$ & $-0.018 * *$ \\
\hline Linguistic minority & $0.014 * *$ & $-0.006 * *$ & $0.017 * *$ \\
\hline Income ladder & $0.005^{* * *}$ & 0.001 & $0.006 * * *$ \\
\hline \multicolumn{4}{|l|}{ Education } \\
\hline Primary & 0.000 & $-0.013 * * *$ & 0.000 \\
\hline Secondary & Ref. & Ref. & Ref. \\
\hline Tertiary & 0.001 & $0.009 * * *$ & 0.001 \\
\hline Employed & -0.003 & $0.006 * *$ & -0.004 \\
\hline \multicolumn{4}{|l|}{ Type of settlement } \\
\hline Rural & 0.000 & -0.002 & 0.000 \\
\hline Urban & Ref. & Ref. & Ref. \\
\hline Metropolitan & -0.006 & $0.009 * *$ & -0.008 \\
\hline Institutional trust & $-0.008 * * *$ & -0.000 & $-0.009 * * *$ \\
\hline Interpersonal trust & 0.003 & $0.002 *$ & 0.003 \\
\hline \multicolumn{4}{|l|}{ Type of public official } \\
\hline Road police & Ref. & Ref & Ref. \\
\hline Registry & $-0.077 * * *$ & $0.142 * * *$ & $-0.102 * * *$ \\
\hline Courts & $-0.085 * * *$ & $-0.134 * * *$ & $-0.102 * * *$ \\
\hline Education (primary and secondary) & $-0.105 * * *$ & $0.080 * * *$ & $-0.135 * * *$ \\
\hline Education (vocational) & $-0.079 * * *$ & $0.060 * * *$ & $-0.101 * * *$ \\
\hline Public health & $-0.024 * * *$ & $0.594 * * *$ & $-0.040 * * *$ \\
\hline Requesting unemployment benefits & $-0.116^{* * *}$ & $-0.076 * * *$ & $-0.137 * * *$ \\
\hline Requesting other social security benefits & $-0.124 * * *$ & $-0.078 * * *$ & $-0.146 * * *$ \\
\hline \multicolumn{4}{|l|}{ Country } \\
\hline Albania & $0.448 * * *$ & $0.162 * * *$ & $0.472 * * *$ \\
\hline Armenia & $0.099 * * *$ & 0.007 & $0.116 * * *$ \\
\hline Azerbaijan & $0.629 * * *$ & $0.185^{* * *}$ & $0.643 * * *$ \\
\hline Belarus & $0.165 * * *$ & $0.088 * * *$ & $0.187 * * *$ \\
\hline Bosnia & $0.034 *$ & $0.053 * * *$ & $0.040 *$ \\
\hline Bulgaria & $0.042 * *$ & $0.071 * * *$ & $0.049 * *$ \\
\hline Croatia & $-0.077 * * *$ & $0.128 * * *$ & $-0.098 * * *$ \\
\hline Czech Republic & 0.017 & $0.123 * * *$ & 0.019 \\
\hline Estonia & $0.060 * * *$ & $0.022 * *$ & $0.071 * * *$ \\
\hline Georgia & $-0.060 * * *$ & $0.067 * * *$ & $-0.075 * * *$ \\
\hline Hungary & $0.136^{* * *}$ & 0.011 & $0.159 * * *$ \\
\hline Kazakhstan & $0.217 * * *$ & $0.109 * * *$ & $0.242 * * *$ \\
\hline Kosovo & $-0.048 * * *$ & $0.310 * * *$ & $-0.062 * * *$ \\
\hline Kyrgyzstan & $0.625 * * *$ & $0.123 * * *$ & $0.640 * * *$ \\
\hline Latvia & $0.046^{* * *}$ & $0.093 * * *$ & $0.054 * * *$ \\
\hline Lithuania & $0.243 * * *$ & $0.070 * * *$ & $0.273^{* * *}$ \\
\hline Macedonia, FYR & -0.011 & $0.204 * * *$ & -0.016 \\
\hline Moldova & $0.238 * * *$ & $0.110 * * *$ & $0.267 * * *$ \\
\hline Mongolia & $0.150 * * *$ & $0.066 * * *$ & $0.168 * * *$ \\
\hline Montenegro & $0.112 * * *$ & $0.061 * * *$ & $0.130 * * *$ \\
\hline Poland & Ref. & Ref. & Ref. \\
\hline Romania & $0.225 * * *$ & $0.030 * * *$ & $0.255 * * *$ \\
\hline Russia & $0.180 * * *$ & $0.091 * * *$ & $0.205^{* * *}$ \\
\hline Serbia & $0.042 * *$ & $0.082 * * *$ & $0.049 * *$ \\
\hline
\end{tabular}




\begin{tabular}{|c|c|c|c|}
\hline Slovakia & 0.022 & $0.107 * * *$ & 0.026 \\
\hline Slovenia & $-0.066 * * *$ & $0.132 * * *$ & $-0.085 * * *$ \\
\hline Tajikistan & $0.474 * * *$ & $0.094 * * *$ & $0.500 * * *$ \\
\hline Turkey & $0.057 * * *$ & $0.017 * *$ & $0.066 * * *$ \\
\hline Ukraine & $0.415 * * *$ & $0.094 * * *$ & $0.446 * * *$ \\
\hline Uzbekistan & $0.436 * * *$ & $0.137 * * *$ & $0.464 * * *$ \\
\hline Selection into contact & - & $0.218 * * *$ & - \\
\hline Number of household-official pairs & \multicolumn{2}{|c|}{261744} & 56189 \\
\hline Number of households & \multicolumn{2}{|c|}{32718} & 26486 \\
\hline Censored observations & \multicolumn{2}{|c|}{205555} & - \\
\hline Uncensored observations & \multicolumn{2}{|c|}{56189} & - \\
\hline Prob $>\mathrm{Chi}^{2}$ & \multicolumn{2}{|c|}{0.000} & 0.000 \\
\hline Pseudo $\mathrm{R}^{2}$ & \multicolumn{2}{|c|}{-} & 0.2011 \\
\hline Rho & \multicolumn{2}{|c|}{-0.091} & - \\
\hline Prob $>\mathrm{Chi}^{2}(R h o=0)$ & \multicolumn{2}{|c|}{0.009} & - \\
\hline
\end{tabular}

Notes: * denotes significance at 10\% level, ** - 5\%, ***-1\%. The unit of observation is household-official pair. Standard errors (not reported to save space) clustered at household level. Complete econometric output is available from authors upon request.

\section{$\underline{\text { Results for different country groups }}$}

In this subsection, we look at the determinants of corruption and the presence of sample selection bias in different parts of the Central Eastern European and Central Asian region, as well as the five Western European countries. We create, along geopolitical lines, the following country groups: the Balkans (Albania, Bosnia and Herzegovina, Bulgaria, Croatia, Kosovo, FYR of Macedonia, Montenegro, Romania, Serbia), the Baltics (Estonia, Latvia, Lithuania), the Caucasus (Armenia, Azerbaijan, Georgia), Central Asia (Kazakhstan, Kyrgyzstan, Tajikistan, Uzbekistan), Central Europe (Czech Republic, Hungary, Poland, Slovakia, Slovenia), Slav ex-USSR (Belarus, Russia, Ukraine), and Western Europe (Germany, France, Italy, Sweden, the UK). ${ }^{9}$

Table 3 reports the marginal effects of the Heckman correction model outcome equation (probability of bribery once the contact with public officials has taken place), as well as the estimated coefficient of correlation between the error terms in the selection and outcome equations (rho). The sample selection bias is present in the Caucasus, Slav ex-USSR and the Central Europe subsamples: the estimated rho term is statistically significant at $99 \%$ level. The Heckman correction model should

\footnotetext{
${ }^{9}$ Moldova, Mongolia and Turkey are excluded from the analysis, as it is difficult to assign them to a particular country groups.
} 
therefore be used for these country groups, while a standard probit would be sufficient for the others.

The results reveal some disparity in the determinants of the bribery decision at country group level. Gender is statistically insignificant in all country groups but Central Asia, where women are 3.7 percentage points less likely to pay bribes than men. The negative association of bribery and age is observed in Central Asia, Slav exUSSR and, to a lesser extent, in Caucasus; the relationship in other country groups is less clear-cut or the coefficients are insignificant. Linguistic minorities are more likely to pay bribes in the Baltics and, especially, the Western European group, while the coefficient for other country groups is statistically insignificant.

Income ladder coefficient is positive in all country groups, but statistically significant only in the Western Europe and the Balkans. In Western Europe, moving from the lowest to the highest step on the ten-step income ladder is associated with 2 percentage points higher likelihood of bribing public officials (the coefficient is significant at the 10 percent level). In the Balkans, the association is stronger both in size and significance: moving from the bottom to top on the relative income ladder is associated with an 8 percentage points increase in the likelihood of bribing public officials, which is significant at the 99 per cent level.

If anything, higher levels of education tend to be associated with lower probability of paying bribes to public officials. In Central Asia and Western Europe, people with primary education are 4.5 and 1.1 percentage points, respectively, more likely to pay bribes compared with those with secondary education (the reference group). At the same time, in the Balkans and Western Europe, people with tertiary education are 2 and 1 percentage points, respectively, less likely to pay bribes relative to the reference group.

For several regressors, the sign of the estimated coefficient depends on the country group. For example, the employed are 1.7 percentage points less likely to pay bribes in Central Europe, but 2.6 percentage points more likely to do so in Slav ex-USSR; the coefficients (and marginal effects) in other country groups are statistically insignificant (and tend to be negative). We also observe an important variation in the 
relationship between bribery and type of settlement. For several country groups, bribery is more likely to be committed in urban areas: compared with people living in urban-non-metropolitan areas (the reference group), those from rural areas in the Caucasus, Central Europe and Western Europe are 3.7, 1.8 and 0.7 percentage points, respectively, less likely to report bribing public officials. Similarly, those living in metropolitan areas in the Slav ex-USSR region are 10.3 percentage points more likely to pay bribes compared with the reference group. An opposite association is observed in Central Asia, where bribery is more widespread in rural areas. Compared with the reference group, the village dwellers there are 6.9 percentage points more likely, and the metropolitan dwellers are 15.8 percentage points less likely, to bribe public officials.

Institutional trust is negatively associated with the probability of bribing public officials in all country groups. The marginal effect is particularly high in Central Asia, where a one unit increase on the institutional trust scale (4 - complete distrust, 20 complete trust) is associated with a 2.7 percentage point lower probability of bribery. Contrary to institutional trust, the relationship between bribery and interpersonal trust differs across country groups. In particular, the conjecture that in order to bribe one needs to trust people is supported in the Caucasus, Central Asian and Western European sub-samples. In these three country groups, an extra step on the 1 (no trust) -5 (complete trust) interpersonal trust scale is associated with $0.1,3.4$ and 0.7 percentage point increase in the probability of bribing public officials, respectively. However, in the Balkans, people with more interpersonal trust are less likely to engage in bribery, an extra step on the 1-5 interpersonal trust scale being associated with a decrease of 0.6 in the probability of bribing.

Considering conditional bribery rates for different types of public officials, the road police are the most corrupt public service in the Balkans, Central Asia and Slav exUSSR, while public health is the most corrupt in the Caucasus and Central Europe. In the Baltics, the road police and public health are equally corrupt and have the highest bribery rates among the eight types of public officials. In Western Europe, there is no statistically significant difference in the conditional bribery rates for the road police, registry, public health and services dealing with unemployment benefits, and there is 0.8-1.5 percentage point decrease in the likelihood of observing a corrupt exchange in 
education and services dealing with social security benefits other than unemployment. Overall, in most country groups, services dealing with the unemployment and other social security benefits, as well as education, tend to be the least corrupt.

Comparing the individual-level determinants of bribery in Western Europe (West) with those in the broad Central Eastern European/ Central Asian region (East), we notice a number of similarities. Linguistic minority status is a significant predictor of bribery in the East - and even more so in the West. People positioning themselves higher on an imaginary income ladder are more likely to bribe public officials in both parts of the world, as are those with lower institutional trust. However, higher levels of education and lower levels of interpersonal trust are associated with lower bribery rates in the West, while the relationship in the East is more opaque. Finally, older respondents are less likely to bribe in the East, while the estimated coefficients of age groups in the West sub-sample are statistically insignificant. ${ }^{10}$

\footnotetext{
${ }^{10}$ We have also compared the average bribery rates, conditional on the observed socio-demographic characteristics, of all countries participating in the survey. Our expectation was that the bribery rates in the West would be lower than those in the East. Running a regression which includes both Western and Eastern European/ Central Asian countries, we found that the public services users in Sweden, Italy, France and the UK are 8.9, 8.0, 6.3 and 5.1 percentage points, respectively, less likely to bribe public officials, compared with the public official users in Poland (the reference group). However, unexpectedly, we found that the probability of bribing, condition on public official use, was 6.4 percentage points higher in Germany than in Poland. This is a puzzling result. One explanation could be that people in Germany tend to be more honest about their involvement in corrupt exchanges, while people in other countries underreport it. Another reconciling factor is that, according to our model, the probability of contacting public officials is lower in Germany than in any other country in the sample. This has an indirect negative effect on bribery, especially if one wants to calculate the bribery rate for whole population of the country (the users and the non-users of public services). The full set of results (the outcome and selection equations) for the whole sample is available on request.
} 
Table 3. Probability of bribery among public official users for different country groups; Heckman probit outcome equation marginal effects.

\begin{tabular}{|c|c|c|c|c|c|c|c|}
\hline & 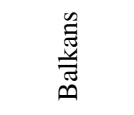 & $\frac{n}{\stackrel{0}{\Xi}}$ & 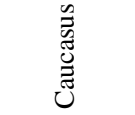 & $\underbrace{\frac{\pi}{U}}_{0} \cdot \frac{\pi}{4}$ & 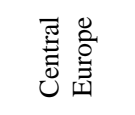 & 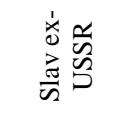 & 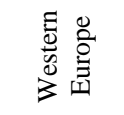 \\
\hline Female & -0.001 & -0.001 & 0.015 & $-0.037 * *$ & -0.000 & 0.002 & 0.000 \\
\hline \multicolumn{8}{|l|}{ Age group } \\
\hline $18-24$ & 0.005 & -0.026 & -0.017 & -0.032 & -0.011 & -0.001 & 0.009 \\
\hline $25-34$ & $0.024 * * *$ & -0.009 & -0.002 & -0.020 & $-0.013 *$ & -0.013 & 0.005 \\
\hline $35-44$ & Ref. & Ref. & Ref. & Ref. & Ref. & Ref. & Ref. \\
\hline $45-54$ & $0.019 * *$ & 0.006 & -0.013 & $-0.043^{*}$ & -0.007 & $-0.042 * *$ & -0.000 \\
\hline $55-64$ & -0.008 & -0.013 & -0.010 & $-0.106^{* * *}$ & -0.008 & $-0.044 * *$ & -0.003 \\
\hline $65+$ & -0.009 & -0.006 & $-0.032 *$ & -0.002 & 0.014 & $-0.096^{* * *}$ & 0.000 \\
\hline Linguistic minority & 0.000 & $0.024 *$ & 0.032 & 0.012 & -0.002 & 0.010 & $0.039 * *$ \\
\hline Income ladder & $0.008 * * *$ & 0.004 & 0.003 & 0.003 & 0.001 & 0.002 & $0.002 *$ \\
\hline \multicolumn{8}{|l|}{ Education } \\
\hline Primary & -0.002 & -0.008 & 0.011 & $0.045^{* *}$ & 0.003 & -0.015 & $0.011^{* *}$ \\
\hline Secondary & Ref. & Ref. & Ref. & Ref. & Ref. & Ref. & Ref. \\
\hline Tertiary & $-0.020 * * *$ & -0.016 & 0.002 & 0.026 & 0.014 & 0.009 & $-0.010^{* *}$ \\
\hline Employed & -0.003 & -0.001 & -0.007 & -0.002 & $-0.017 * *$ & $0.026^{*}$ & -0.002 \\
\hline \multicolumn{8}{|l|}{ Type of settlement } \\
\hline Rural & 0.006 & $-0.029 * *$ & $-0.037 * * *$ & $0.069 * * *$ & $-0.018 * * *$ & -0.004 & $-0.007 * *$ \\
\hline Urban & Ref. & Ref. & Ref. & Ref. & Ref. & Ref. & Ref. \\
\hline Metropolitan & -0.001 & $-0.044 * * *$ & -0.014 & $-0.158 * * *$ & 0.005 & $0.103 * * *$ & -0.001 \\
\hline Institutional trust & $-0.005 * * *$ & $-0.003^{*}$ & $-0.004 * * *$ & $-0.027 * * *$ & $-0.003^{* * *}$ & $-0.006^{* * *}$ & $-0.001 * *$ \\
\hline Interpersonal trust & $-0.006 * *$ & 0.003 & $0.010 * *$ & $0.034 * * *$ & -0.000 & -0.000 & $0.007 * * *$ \\
\hline \multicolumn{8}{|l|}{ Type of public official } \\
\hline Road police & Ref. & Ref. & Ref. & Ref. & Ref. & Ref. & Ref. \\
\hline Registry & $-0.060 * * *$ & $-0.092 * * *$ & $-0.036^{* *}$ & $-0.180 * * *$ & -0.003 & $-0.160 * * *$ & 0.004 \\
\hline Courts & $-0.062 * * *$ & $-0.081 * * *$ & -0.027 & $-0.262 * * *$ & 0.010 & $-0.164 * * *$ & 0.009 \\
\hline Education (prim./sec.) & $-0.083^{* * *}$ & $-0.088 * * *$ & $-0.094 * * *$ & $-0.337 * * *$ & $-0.013^{*}$ & $-0.106^{* * *}$ & $-0.008^{*}$ \\
\hline Education (vocat.) & $-0.071 * * *$ & $-0.081 * * *$ & $-0.068 * * *$ & $-0.209 * * *$ & -0.003 & $-0.095 * * *$ & $-0.015 * * *$ \\
\hline Public health & $-0.015 * *$ & -0.006 & $0.031 *$ & $-0.204 * * *$ & $0.097 * * *$ & $-0.033 * *$ & 0.003 \\
\hline Unemployment benefits & $-0.078 * * *$ & $-0.080 * * *$ & $-0.124 * * *$ & $-0.293 * * *$ & -0.011 & $-0.188 * * *$ & -0.009 \\
\hline Other benefits & $-0.080 * * *$ & $-0.076^{* * *}$ & $-0.131 * * *$ & $-0.317 * * *$ & -0.004 & $-0.204 * * *$ & $-0.011 * *$ \\
\hline Number of household-official pairs & 78512 & 23704 & 23744 & 35200 & 44496 & 32176 & 43552 \\
\hline Number of households & 9814 & 2963 & 2968 & 4400 & 5562 & 4022 & 5444 \\
\hline Censored observations & 60130 & 19373 & 18708 & 26614 & 35968 & 25452 & 36502 \\
\hline Uncensored observations & 18382 & 4331 & 5036 & 8586 & 8528 & 6724 & 7050 \\
\hline Prob $>\mathrm{Chi}^{2}$ & 0.000 & 0.000 & 0.000 & 0.000 & 0.000 & 0.000 & 0.000 \\
\hline Rho & 0.035 & 0.076 & -0.354 & -0.039 & -0.350 & -0.194 & -0.084 \\
\hline Prob $>\mathrm{Chi}^{2}(\mathrm{Rho}=0)$ & 0.620 & 0.512 & 0.000 & 0.625 & 0.000 & 0.007 & 0.643 \\
\hline
\end{tabular}

Notes: * denotes significance at $10 \%$ level, ** - 5\%, *** - 1\%. The unit of observation is household-official pair. Standard errors, clustered at household level, and country fixed effects are not reported to save space. The Balkans: Albania, Bosnia and Herzegovina, Bulgaria, Croatia, Kosovo, FYR of Macedonia, Montenegro, Romania, Serbia; the Baltics: Estonia, Latvia, Lithuania; the Caucasus: Armenia, Azerbaijan, Georgia; Central Asia: Kazakhstan, Kyrgyzstan, Tajikistan, Uzbekistan; Central Europe: Czech Republic, Hungary, Poland, Slovakia, Slovenia; Slav ex-USSR: Belarus, Russia, Ukraine; Western Europe: Germany, France, Italy, Sweden, the UK. Complete econometric output, including the results for selection equations, is available on request.

\section{Conclusion}

This paper has sought to explore the individual-level determinants of bribing public officials in 30 post-socialist and five Western European countries. The probit model with a Heckman correction was used to detect and control for a possible sample 
selection bias arising when people self-select into contact with public officials on the basis of unobservable characteristics.

Our results suggest that, in the post-socialist world, the elderly are less likely to pay bribes to public officials, while linguistic minorities, people with higher perceived relative income and those with lower trust in public institutions are more likely to do so. We also notice that the minority status, higher perceived relative income and lower institutional trust are positively correlated with a higher probability of bribing public officials in Western Europe, implying a considerable similarity in the microdeterminants of bribery in these two distinct parts of Europe/Central Asia.

Several factors, however, play a different role in different country groups. For example, people with higher levels of education are less prone to corruption in the Balkans, Central Asia and Western Europe, while the coefficient of education is insignificant in other country groups. Urban residents are more likely to bribe public officials in the Caucasus, Central Europe and the Slav ex-USSR, while rural dwellers are more likely to bribe in Central Asia. Finally, greater trust in people is associated with a higher probability of bribery in the Caucasus, Central Asia and Western Europe and a lower probability of bribery in the Balkans.

The use of the Heckman correction procedure suggests that, for several country groups, a sample selection due to a non-random selection of people into contact with public officials is present. When the selection bias is not controlled for in a broad group of post-socialist countries, marginal effect estimates are on average biased upwards by 19 per cent. Our recommendation, therefore, is that researchers, who study bribing behaviour, control for sample selection effects or, at least, be aware of upwards biases when interpreting results. 


\section{References}

Ali, A.M., and Isse, H.S. (2003) "Determinants of economic corruption: a crosscountry comparison" Cato Journal 22: 449-466.

Baum, C. (2006) An Introduction to Modern Econometrics Using Stata, Stata Press, College Station, TX.

Brunetti, A and Weder, B. (2003) "A free press is bad news for corruption" Journal of Public Economics 87: 1801-1824.

Cuervo-Cazurra, A. (2006) "Who cares about corruption?" Journal of International Business Studies 37: 803 - 822.

Egger, P. and Winner, H. (2006) "How Corruption Influences Foreign Direct Investment: A Panel Data Study" Economic Development and Cultural Change 54 (2): 459-486.

Everhart, S, Martinez-Vazquez, J., and McNab, R. (2009) "Corruption, governance, investment and growth in emerging markets" Applied Economics 41(13): 1579-1594.

Gatti, R., Paternostro, S. and Rigolini, J. (2003) "Individual attitudes toward corruption: do social effect matters?" World Bank Policy Research Working Paper 3122. World Bank, Washington.

Guerrero, M.A., and Rodriguez-Oreggia, E. (2008) "On the individual decisions to commit corruption: A methodological complement" Journal of Economic Behavior and Organization 65: 357-372.

Gupta, S., Davoodi, H. and Alonso-Terme, R. (2002) "Does Corruption Affect Income Inequality and Poverty?” Economics of Governance 3: 23-45.

Heckman, J. (1979) "Sample selection bias as a specification error" Econometrica 47: $153-161$.

Hunt, J. (2007) "How corruption hits people when they are down" Journal of Development Economics 84(2): 574-589.

Hunt, J., and Laszlo, S. (2012) "Is bribery really regressive? Bribery's costs, benefits, and mechanisms" World Development 40(2): 355-372.

Iwasaki, I., and Suzuki, T. (2012) "The determinants of corruption in transition economies" Economics Letters 114: 54-60.

Johnson, N., La Fountain, C., and Yamarik, S. (2011) "Corruption is bad for growth (even in the United States)" Public Choice 147: 377-393.

Jong, De.E., and Bogmans, C. (2011) "Does corruption discourage international trade?" European Journal of Political Economy 27(2): 385-398. 
Jong-sun, Y. Khagram, S. (2005) "A comparative study of inequality and corruption" American Sociological Review, 70 (1): 136-157.

Mauro, P. (1995) “Corruption and growth" Quarterly Journal of Economics 110(3): $681-712$.

Mocan, N. (2008) "What determines corruption? International evidence from micro data" Economic Inquiry 46(4): 493-510.

Sööt, M.-L. and Rootalu, K. (2012). "Institutional Trust and Opinions of Corruption" Public Administration and Development 32(1): 82-95.

Steves, F. (Ed.) (2011) Life in transition: After the crisis. London: European Bank for Reconstruction and Development \& World Bank.

Swamy, A., Knack, S., Lee, Y., and Azfar, O. (2001) “Gender and Corruption” Journal of Development Economics 64(1): 25-55.

Tavits, M. (2010) "Why do People Engage in Corruption? The Case of Estonia" Social Forces 88(3): 1257-1280.

Transparency International (2011) Corruption Perceptions Index 2011, Transparency International.

Treisman, D. (2000) “The Causes of Corruption: A Cross-National Study” Journal of Public Economics 76(3): 399-457.

Truex, T. (2011) "Corruption, Attitudes, and Education: Survey Evidence from Nepal” World Development 39(7): 1133-1142.

Van de Ven, W. P. M. M., and Van Praag, B. M. S. (1981). "The demand for deductibles in private health insurance: A probit model with sample selection" Journal of Econometrics 17: 229-252.

Van Rijckeghem, C., and Weder, B. (2001) "Bureaucratic corruption and the rate of temptation: do wages in the civil service affect corruption, and by how much?" Journal of Development Economics 65: 307-332.

Vella, F. (1998) "Estimating models with sample selection bias: a survey" The Journal of Human Resources 33: 127-169.

Wei, S.-J. (2000) "How taxing is corruption on international investors?" Review of Economics and Statistics 82: 1-11.

Wooldridge, J. M. “2002” Econometric Analysis of Cross Section and Panel Data. Cambridge, MA: MIT Press. 
Appendix.

Summary statistics of variables included in the analysis.

\begin{tabular}{|c|c|c|c|c|c|c|c|c|}
\hline & \multicolumn{3}{|c|}{$\begin{array}{c}\text { Central Eastern Europe and } \\
\text { Central Asia }\end{array}$} & \multicolumn{3}{|c|}{ Western Europe } & \multirow[b]{2}{*}{ Min } & \multirow[b]{2}{*}{ Max } \\
\hline & $\mathrm{N}$ & Mean & St.dev. & $\mathrm{N}$ & Mean & St. dev. & & \\
\hline Female & 33316 & 0.611 & 0.487 & 5504 & 0.558 & 0.497 & 0 & 1 \\
\hline Age 18-24 & 33340 & 0.127 & 0.333 & 5503 & 0.061 & 0.239 & 0 & 1 \\
\hline Age $25-34$ & 33340 & 0.203 & 0.402 & 5503 & 0.135 & 0.341 & 0 & 1 \\
\hline Age $35-44$ & 33340 & 0.185 & 0.388 & 5503 & 0.202 & 0.401 & 0 & 1 \\
\hline Age $45-54$ & 33340 & 0.172 & 0.378 & 5503 & 0.195 & 0.396 & 0 & 1 \\
\hline Age $55-64$ & 33340 & 0.148 & 0.355 & 5503 & 0.186 & 0.389 & 0 & 1 \\
\hline Age $65+$ & 33340 & 0.164 & 0.371 & 5503 & 0.222 & 0.416 & 0 & 1 \\
\hline Linguistic minority & 33360 & 0.133 & 0.339 & 5504 & 0.075 & 0.263 & 0 & 1 \\
\hline $\begin{array}{l}\text { Perceived position on } \\
1-10 \text { income ladder }\end{array}$ & 32789 & 4.324 & 1.674 & 5446 & 4.933 & 1.699 & 1 & 10 \\
\hline Primary education & 33351 & 0.302 & 0.459 & 5503 & 0.351 & 0.477 & 0 & 1 \\
\hline Secondary education & 33351 & 0.505 & 0.500 & 5503 & 0.394 & 0.489 & 0 & 1 \\
\hline Tertiary education & 33351 & 0.193 & 0.395 & 5503 & 0.256 & 0.436 & 0 & 1 \\
\hline Employed & 33360 & 0.480 & 0.500 & 5504 & 0.582 & 0.493 & 0 & 1 \\
\hline Rural & 33360 & 0.417 & 0.493 & 5504 & 0.299 & 0.458 & 0 & 1 \\
\hline Urban & 33360 & 0.462 & 0.499 & 5504 & 0.509 & 0.500 & 0 & 1 \\
\hline Metropolitan & 33360 & 0.121 & 0.327 & 5504 & 0.193 & 0.394 & 0 & 1 \\
\hline Institutional trust & 33360 & 11.596 & 3.992 & 5504 & 12.550 & 3.261 & 4 & 20 \\
\hline Interpersonal trust & 33360 & 2.939 & 1.030 & 5504 & 3.070 & 1.001 & 1 & 5 \\
\hline $\begin{array}{l}\text { Selection into } \\
\text { contact }^{\mathrm{a}}\end{array}$ & 266880 & 0.247 & 0.431 & 44032 & 0.264 & 0.441 & 0 & 1 \\
\hline $\begin{array}{l}\text { Contacted public } \\
\text { officials }^{\mathrm{a}}\end{array}$ & 266880 & 0.215 & 0.410 & 44032 & 0.161 & 0.368 & 0 & 1 \\
\hline $\begin{array}{l}\text { Paid bribe once } \\
\text { contact with public } \\
\text { officials has taken } \\
\text { place }^{\mathrm{a}}\end{array}$ & 57247 & 0.212 & 0.409 & 7108 & 0.033 & 0.178 & 0 & 1 \\
\hline
\end{tabular}

${ }^{\mathrm{a}}$ Based on stacked (household-official pairs) data 